\title{
ASSESSMENT OF THE PHYSICAL ACTIVITY LEVEL FOR THE STAFF MILITARY PERSONNEL
}

\author{
Liana Pļavinga \\ National Defence Academy of Latvia, Riga, Latvia
}

\begin{abstract}
Sport and physical activity is an important and compulsory part for the people who connect their lives with the military system. The military speciality and the quality of execution of the service duties and tasks depends on the fitness level and physical preparedness. We have provided the assessment of physical activity for the staff personnel that is involved in the administration staff work. Otherwise each military officer should be ready to fulfil orders and tasks. Effective and active military service is impossible without an appropriate level of physical preparedness. We have provided the questionnaire for staff officers in 2009-2010 ( $n=52)$. The questionnaire embraced all kinds of physical activities during the daytime. We have received information about sports and physical activity during the service time and free time, the received data about the participation in morning physical activities, the use of the stairs (to go upstairs and downstairs), the execution of physical exercises during the working hours and sports activities after working hours and in the weekend, taking part in the sport events, physical work at home. We have the data of the self-assessment concerning overweight, smoking and alcohol using, the regular regime (sleeping hours and the diet). We have included the questions concerning health problems (the cardiovascular disease, the gastrointestinal disease, the respiratory disease, trauma and ect) and the duration of medical incapability (days per year). We have calculated the points of the physical activity questionnaire. After that we divided the respondents into four groups (lower, moderate, good and high) according to the results of the level of physical activity. The assessments of the physical activity level allow correlating the life style, and the support and keep physical preparedness and develop physical abilities of the staff personnel.
\end{abstract}


Key words: Physical activity, military personnel.

\section{INTRODUCTION}

Sport and physical activity is an important and compulsory part of the military personnel life. The military speciality and the quality of execution the service duties and tasks depends on the fitness level and physical preparedness $[6,8,9]$. We have provided the assessment of physical activity for the staff personnel that is involved in the administration, the staff work. Otherwise a military officer should be ready to fulfil the orders, tasks. The execution of service duties could not be possible without the appropriate level of physical preparedness $[12,13,14]$. Regular physical exercises have health benefits in relation to cardiovascular and metabolic diseases $[1,10,11]$. It is very important to motivate individuals to be active that allows keeping physical preparedness on the appropriate level and developing physical abilities $[2,4,5,6,7]$.

\section{MATERIAL AND METHODS}

We have provided the questionnaire for the staff officers in $2009(\mathrm{n}=22)$ and $2010(n=30)$. The staff officers aged from 28 years to 37 years.

The questionnaire includes the positions that allow us to collect the information about sport and physical activity during the service time and after it [3]. The questionnaire embraced all the spectrum of the day's physical activities: morning physical activities, the use of the stairs (to go upstairs and downstairs), physical exercise during the working hours, sports activities after working hours, and in the weekend, participation in the sport events, physical work at home, the self-assessment concerning overweight, smoking and alcohol using, regular sleeping hours and the diet. Regular physical activities have beneficial effects in general and particularly in relation to cardiovascular and metabolic diseases. We included the questions related to health problems (cardiovascular, respiratory, gastrointestinal diseases, trauma and ect) and the duration of medical incapability (days per year). The data of the questionnaire were evaluated according to the scale (in points) and calculated. Those allow us to divide respondents into groups according to the levels of physical activity (low, moderate, and good, high). 


\section{RESULTS AND DISCUSSION}

The questionnaire contains about eleven positions, each one gets evaluation in points. We have calculated the total daily physical activity level (account of points) and received results. The respondents are divided into four groups according to the level of physical activity: low, moderate, good, high. According to the questionnaire results the low level of physical activity in 2009-2010 was in $23.3 \%-31.8 \%$ of respondents, the moderate level of physical activity in $20-45.4 \%$, the good level of physical activity in $22.7 \%-23.3 \%$ of respondents, the high level of physical activity in $33.3 \%$ of the respondents in 2010 and no one in 2009 (Figure 1).

Morning physical activities have favourable influence upon the working capacities. Respondents' answers have shown that $13.6 \%$ respondents in 2009 and $13.3 \%$ in 2010 have morning physical exercises. There were $23.3 \%$ of respondents in 2010 and two times more respondents $(54.5 \%)$ in 2009 that did not at all make morning physical activities (Figure 2).

In the modern society when the distance between the office and the living apartment is large, we would like to get information about sports (physical) activities of respondents during the week, during the weekend, and about the duration and frequency of sport activities. All the respondents have physical activities (Figure 3) during the week time or in the weekend. The majority of respondents have regular physical activities during the week (after service) or in the weekend $31.8 \%$ (2009) and 60\% (2010). Physical activities during the service time have regularly $31.8 \%$ (2009) and $43.3 \%$ (2010) of respondents. The duration of sport exercises was variable from 2 hours to 8 hours per week. There are about $6.6 \%$ of respondents who spend up to 2 hours for physical activities in the week, $10 \%$ of respondents spend more than $10 \mathrm{hrs}$ for sport activities, the majority of respondents spend for sport activities about 3-6 hours per week. We have asked the questions concerning the respondents' attitude to using the elevator or stairs. The results of the questionnaire showed that $68.2 \%$ (2009) and $63.3 \%$ (2010) of respondents regularly used the stairs. Only $3.3 \%$ in 2010 and $18.2 \%$ of the respondents in 2009 do not like stairs and use the elevator where it is possible. 


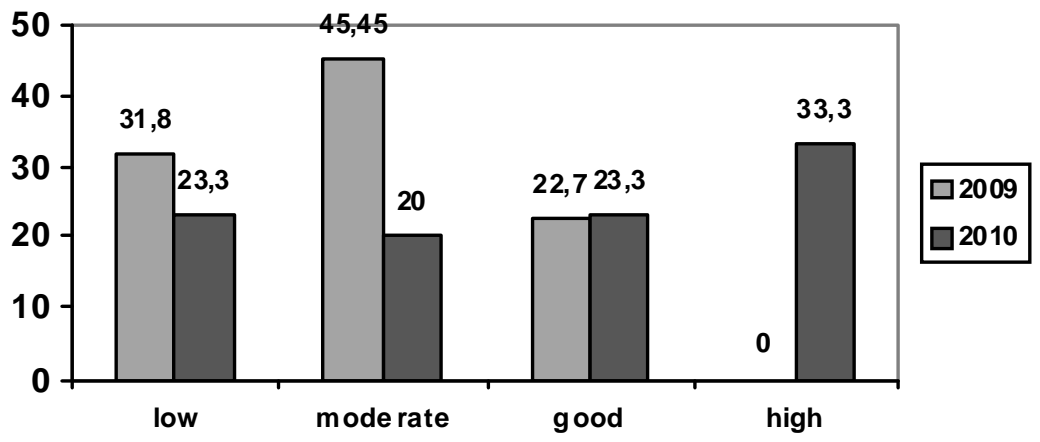

Figure1. Distribution of respondents according to the physical activity level $(\%)$.

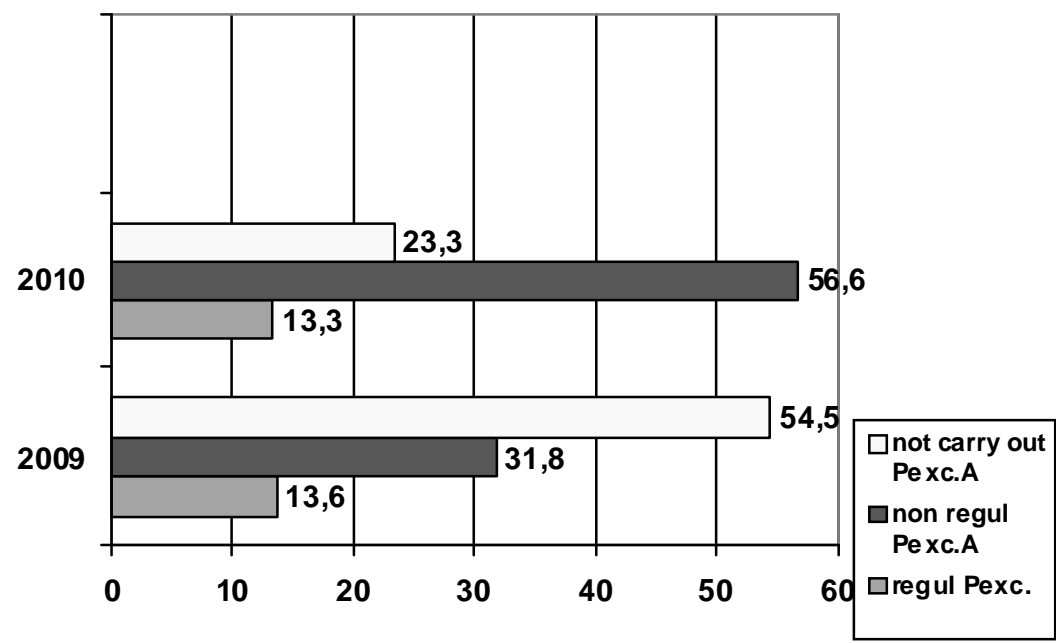

Figure 2. Respondent's attitude to morning physical exercises (\%). 


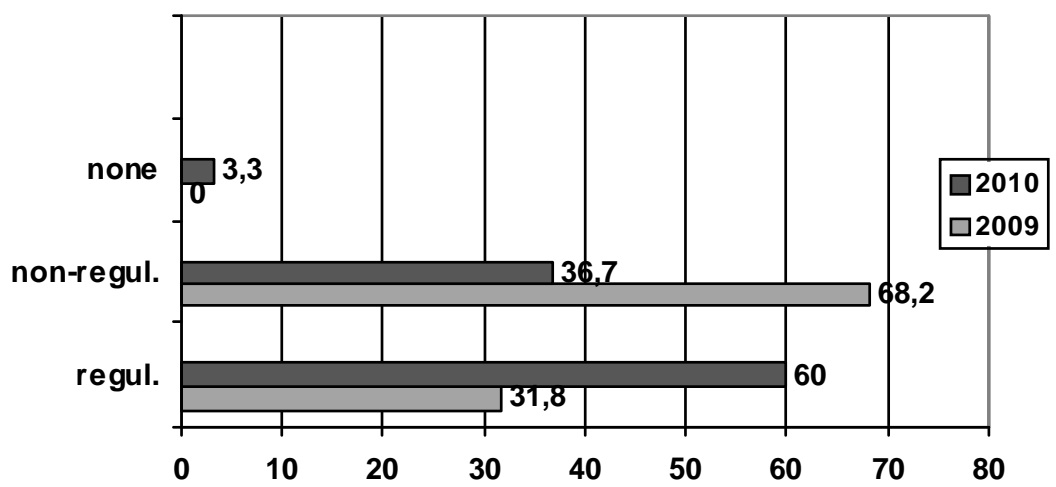

Figure 3. Physical activities of respondents in week/weekend (\%).

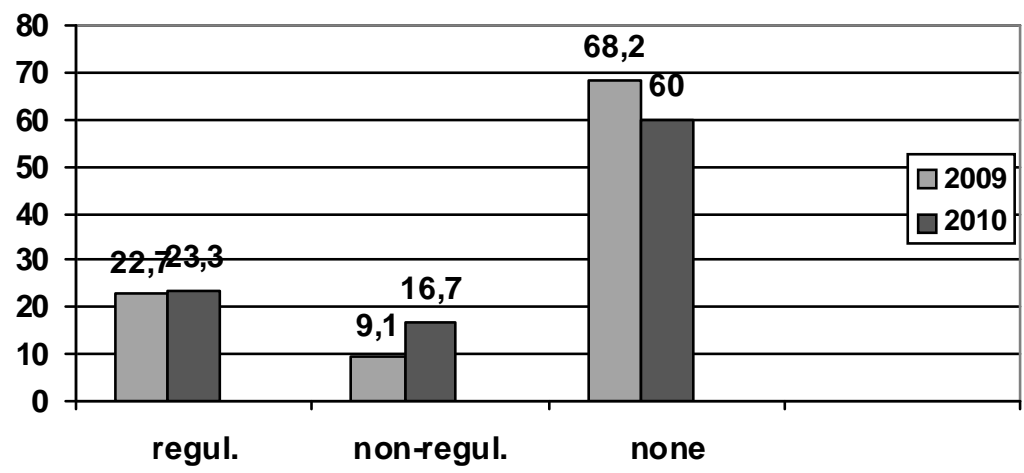

Figure 4. Speadwide of smoking in respondent groups(\%).

The negative impact on the health and well-being is exercised by bad habits (smoking, using of strong alcohol, ignoring the regular meals and sleeping insufficient). We have asked questions about these problems in the questionnaire and receioved such feedback. Regular smokers in the staff personnel $22.7 \%$ in 2009 and in $23.3 \%$ of respondents $2010 ; 4.5 \%$ of respondents (2009) and 20\% (2010) did not use alcohol at all; $13.6 \%$ of respondents (2009) and 16.6\% (2010) have less than 6 hours of sleeping time. 
We have received the information that about $77.3-80 \%$ of respondents get medical illness certificate for 5 days per year. The reasons of incapacity were related to health problems such as trauma in $77.3-80 \%$ cases, respiratory diseases- in $22.7 \%-33.3 \%$ cases, skeleton and muscular diseases in $18.2 \%$ cases, cardiovascular diseases in $3.3 \%$ cases.

During the daily activities individuals have physical activities outside the service, it could be organized at the home, in the garden, outside the house ect. We asked the question about the respondents' attitude and participation in these activities. We have received positive answers (confirming participation in home physical activities) from $36.4 \%$ (2009) and 46.7\% (2010) respondents; 59.1\% (2009) and 53.3\% (2010) have no regular physical activities at home, but 4.5\% (2009) of respondents did not take part in physical activities at home at all.

In the modern society when the distance between the office and the living apartment is large, people use transport (individual or public) for travelling from home to office. Walking as a physical activity is not widely spread. We ask a question about the regular daily walking to the office and back home. We received such data: $54.5 \%$ of respondents in 2009 and $36.7 \%$ of respondents in 2010 did not walk from home to office and back. They use any kind of transportation. But 54.5\% (2009) of respondents and $36.7 \%$ (2010) of respondents regularly walk to office.

\section{CONCLUSION}

1. The low level of physical activity indicated the problems to pass annual physical tests and the problems of physical fitness. The respondents in that group can get health problems overload, the harmful effect of physical load during service or mission. The lower level of physical activity according to the questionnaire was fixed for $31.8 \%$ staff officers in 2009 and $23.3 \%$ of staff officers in 2010 . The moderate level of physical activity was determined for $45.5 \%$ of respondents in 2009 and $20 \%$ of respondents in 2010, the good level of physical activity characterizes $22.7 \%$ (2009) and 23.3\% (2010). The high level of physical activity was recognized for $33.3 \%$ of respondents in 2010, but in 2009 there was no person with a high level of physical activity. 
2. The respondents preferred the physical activities during the week/weekend regularly $31.8 \%$ in 2009 and $60 \%$ in $2010 ; 68.17 \%$ of respondents in 2009 and $36.7 \%$ of respondents in 2010 have no regular physical activities. The personnel have the motivation to be active and to keep physical preparedness.

3. Regular morning physical activities characterize $13.3 \%$ of respondents $(2010)$ and $54.5 \%$ in $2009 ; 13.6-23.3 \%$ of respondents did not spend the time for morning physical activities.

4. $22.7 \%$ of respondents in 2009 and $23.3 \%$ of respondents in 2010 were smokers. Smoking has a negative impact on health, on physical readiness;. 60-68.2\% of respondents do not smoke at all.

5. Self-estimation revealed that overweight problems were fixed for about $13.3 \%$ of the respondents in 2010 and $63.6 \%$ in 2009 . The most spread healthy problems were connected to the respiratory system disease and to trauma.

\section{REFERENCES}

1. Dishman R., Flemmunig D., Kjaer M. (2007) Why exercise ? Book of Abstract $12^{\text {th }}$ Annual Congress of the ECSS, 11-14 July 2007, Jyväskylä, Finland. p. 1.

2. Labudová J. (2002) Place and role of adapted physical activity in sport sciences: Proceedings book: Kinesiology New perspectives - 3rd International Scientific Conference. - Opatija, Croatia, Sept. 25. -29.,391$393 \mathrm{p}$.

3. Виленский М.Я.бИльинский В.И. (1987)Физическая культура работников умственного труда. - Москва:Знание.

4. Laudanska-Krzeminska I. (2003) Physical activity and other health behaviours on the example of working people: New ideas in Sport Sciences. $-8^{\text {th }}$ International Scientific Conference. - P. 2, Vol.15, Warsaw-Poznan-Leszno, 157-160.

5. Prskalo I. (2002) Physiological workload and additional exercising in physical education lessons: Proceedings book: Kinesiology New perspectives. - 3rd International Scientific Conference. - Opatija, Croatia, Sept.25. - 29, 102-104.

6. Umbraško A(2004) Fiziskās sagatavotības īpatnības un tendences dažādu valstu bruṇotajos spēkos. - RTU Zinātniskie raksti Humanitārās un sociālās zinātnes Sērija 8, Sējums 6, Rīga, 230-236. 
7. Ojamaa M., Landōr A, Ignatjevs N., Maaroos (2004) J. Anthropometric indices and health related behaviors among female university students. - Papers on Anthropology XIII. - University of Tartu, 176-184.

8. Contramestre J, Marques A, Alves Diniz J, Carreiro da Costa F. (2007) Relationship between objective fitness evaluation and perception of health and fitness in the Portuguese military academy students. Book of Abstract 12 ECSS, 11-14 July 2007. - Jyväskylä, Finland.384.

9. Labalaiks Z, Dravnieks J. (2008) The control model of physical fitness at the national armed forces of Latvia, Book of Abstract 13 ECSS, 9-12 July 2008. - Estoril, Portugal.229.

10. Sallis J. Helping people become more physically acive: from individual to environmental interventions (2007) Book of Abstract $12^{\text {th }}$ Annual Congress of the ECSS, 11-14 July 2007, Jyväskylä, Finland. p. 3.

11. Oja P. (2007) Sport for all - sport for publicē health? Book of Abstract $12^{\text {th }}$ Annual Congress of the ECSS, 11-14 July 2007, Jyväskylä, Finland. p. 3.

12. Antson H, Märks H. (2007) Reappeared and new overuse injuries in conscripts caused by diffrent kinds of duty in unit of Estonian Army// Book of Abstract 12 ECSS, 11-14 July 2007. - Jyväskylä, Finland. 421-422.

13. Antson H, Märks H. (2008) The diseases of the musculoskeletal system and conscripts' physical readiness related to this in the unit of the Estonian Army. Book of Abstract 13 ECSS, 9-12 July 2008. - Estoril, Portugal. 575-576.

14. NascimentoR, Martinez E, De Sa Rego Fortes (2008) Relationship between physical fitness body fat mass and coronary risk factors in military Brazilian males Book of Abstract 13 ECSS, 9-12 July 2008. Estoril, Portugal.110.

\section{Address for correspondence:}

Liana Pḷavina

National Defence Academy of Latvia

LV-1014, Ezermalas str. 8, Riga, Latvia

Tel.(+371 29208611) 